\title{
The Effects of Institutional Measures: Geographical Indication in Mercosur and the EU
}

\author{
Guilherme Silva Fracarolli 1,2 (D) \\ 1 SOCIUS-Research Centre in Economic and Organizational Sociology, ISEG-School of Economics and \\ Management, University of Lisbon, 1249-078 Lisbon, Portugal; guilherme.fracarolli@phd.iseg.ulisboa.pt \\ 2 Rural Development Division, Federal Superintendence of Agriculture, Livestock and Supply of São Paulo, \\ Ministry of Agriculture, Livestock and Food Supply, 01327-002 São Paulo, Brazil; \\ guilherme.fracarolli@agricultura.gov.br
}

check for updates

Citation: Fracarolli, G.S. The Effects of Institutional Measures: Geographical Indication in Mercosur and the EU. Sustainability 2021, 13, 3476. https://doi.org/10.3390/ su13063476

Academic Editor: Giovanni Belletti

Received: 1 March 2021

Accepted: 18 March 2021

Published: 21 March 2021

Publisher's Note: MDPI stays neutral with regard to jurisdictional claims in published maps and institutional affiliations.

Copyright: (C) 2021 by the author. Licensee MDPI, Basel, Switzerland. This article is an open access article distributed under the terms and conditions of the Creative Commons Attribution (CC BY) license (https:/ / creativecommons.org/licenses/by/ $4.0 /)$.

\begin{abstract}
As agri-food markets become increasingly specialized, governments are provoked to provide these products legal support to protect their supply and trade sources. After several treaties, the Trade-Related Aspects of Intellectual Property Rights (TRIPS) Agreement was signed in 1995 as the broadest ever reached. The agreement allowed Geographical Indication (GI) of agri-food products to be targeted. The GIs of Mercosur and the European Union are very different in absolute and relative numbers, showing evidence of significant institutional participation difference. Thus, this work aims to compare the effects of institutional mechanisms promoted by Mercosur and the EU on this market by establishing an analysis framework based on the respective laws and agreements against demographic data. The results show that adherence to TRIPS is a necessary condition but not sufficient for its development. Adherence to the Lisbon Agreement also strengthens the capacity to sustain a substantial GI market. Additionally, the standardization of regulatory treatment and interventionist action helps stabilize and promote institutions in the GI market. Finally, this study concludes from the EU and Mercosur cases that a more robust, promotive and uniform system through its legal basis and dedicated structures results in more trustable institutions and potentially a more abundant market for GI products.
\end{abstract}

Keywords: economic sociology; institutions; Mercosur; European Union; geographical indication; comparative approach

\section{Introduction}

As agri-food markets become increasingly specialized, governments are provoked to provide these products legal support to promote their supply and trade sources. However, agricultural markets are not all the same. There are clearly at least two very distinct types. On the one hand, highly standardized products, in large volume and regardless of production origin, known as commodities. On the other hand, products are often handcrafted, linked to the origin of production and on a small scale, which characterizes niche markets. In these niche markets for agri-food products, the Geographical Indication (GI) stands out, although some GI products also have an industrial scale. Even so, because they have an essential territorial link, they cannot only be transported to other regions or expand production unrestrictedly. Factors like these keep GI products away from commodities. At this point, the paradox of "logic of quality" in opposition to a "productivist logic," highlighted by Allaire and Sylvander (1997) [1], stands out. As Bonanno (2020) [2] stated, GI is a tool that opposes neoliberal globalization that develops and democratizes the agri-food sector.

Although origin attribution of agri-food products has been used for millennia, there has been a regulatory norm only since the 19th century. From that moment, it was necessary to instrumentalize GIs beyond a marketing strategy due to the asymmetry of information and moral hazard problems identified over a broad meaning of markets by Akerlof 
(1970) [3]. Therefore, it could be transformed into an instrument with a dual purpose of protecting producers regarding consumers' commercial interests to guarantee the authenticity of origin and adoption of qualitative standards [4].

Nowadays, the established concept for these signs is that GIs are those "which identify a good as originating in the territory of a Member (of World Trade Organization-WTO), or a region or locality in that territory, where a given quality, reputation or another characteristic of the good is essentially attributable to its geographical origin" [5]. Alternatively, it is merely a result of years of combinations of social, economic, cultural, and technical factors that create a unique product linked to a particular region due to know-how and terroir. Due to their nature, these products form a relevant market niche that opposes scale agriculture [6]. Depending on other factors, they can contribute to this market and promote the region [7].

The European Union (EU) and the Southern Common Market (Mercosur) constitute different unions between countries. Although both constitute economic blocs, there are subtle but relevant differences between them. While the first is the union of 27 sovereign states, aiming to create and develop standard policies for economic, political and security cooperation, the latter is an "imperfect Customs Union" [8]. This difference can significantly impact the development of supra-state policies and the facilitation of trade in products of this nature.

The number of registrations in the Mercosur and the EU GI agri-food markets points to a significant difference. While the EU has 3300 among all sectors of the bloc's products [9], Mercosur has only 221 products from the bloc's five member countries [10]. Considering the composition of this market niche based on the pillars of producers, institutions, and consumers [7], the explanation for such a difference may be partially the result of state participation.

State action on commercial matters, although controversial, is a mechanism used to a greater or lesser extent across the globe. Precisely because of the differences adopted between countries and economic blocs, there is a need to deepen how the standardization influences the agri-food products market with GI, where little work has been done. In this area, this work focuses on comparatively deepening the mechanisms of how supra-state standards reflect on these products' market.

How states organize themselves to regulate and deal with the GI market raised a question: How do supranational organizations address the theme of this market? Therefore, this work aims to compare the EU and Mercosur GI systems from an institutional perspective.

Markets as social constructions constitute an exchange arena where the actors involved interact under formal and informal rules promoting products' negotiation to provide stability for producers, consumers, and sellers [11,12]. The food market is no different and follows the same logic $[13,14]$. Therefore, research indicates that the State's performance is crucial for understanding this market $[7,13,15,16]$. These findings regarding market functioning mechanisms show how institutions interfere by promoting a trustable or constraining environment.

It is crucial to investigate it through the participation of institutions, which in this case, act on the construction of formal rules through property rights. These institutions and legal aspects are addressed in the next section. Therefore, this work contributes to identifying aspects that influence this market of GIs. These findings were obtained through a thorough review of the institutional parameters by comparing the aspects of laws and agreements and analyzing the implications of such legal aspects. To do so, the methodology is covered in Section 3. Finally, this study frames the legal basis that regulates and impacts the GI market's success and failures regarding institutions and points out the crucial institutional factors. This is done in Section 4 by presenting all the results from the developed framework. After that, in Section 4, the results are discussed and deepened to demonstrate this approach's causes and effects. This is done with the 
hope of contributing to the possible market improvement of specialized trust in agri-food products-building towards regional development, as concluded in Section 5.

\section{Agreements, Institutions and the Agri-Food Market}

\subsection{Treaties Milestones}

The pressure for measures to protect producers from counterfeits and frauds has grown to the point that national organizations can no longer ignore it. Especially in the agricultural field, due to the lack of wine at the end of the 19th century in France with severely compromised local vineyards, the counterfeiting and sale of low-quality wines has increased. This moment was a historic opportunity for the birth of the institutionalization of a new product market in which the products have ties to their origin, making France already in the 20th century the pioneer in this market by institutionalizing it and creating the National Institute of Appellations of Origin for Wines and Spirits (INAO) for this purpose.

In the 19th century, France, aware of the theme's importance, hosted the Paris Convention. Then, in 1883, the first multilateral agreement on intellectual property (IP) was signed, giving rise to the Paris Convention for the Protection of Industrial Property, which remains in force today, managed by the World Intellectual Property Organization (WIPO). The treaty created the bases for national treatment, priority rights and standard rules, which still guide regulations. The theme is so important that the treaty, initially signed by 11 countries, has 177 members after its revisions.

Madrid was also a crucial stage for multilateral IP regulation as it hosted two binding agreements that make up the Madrid System. In 1891, the Madrid Agreement Concerning the International Registration of Marks established an international registration system but had little success. The second agreement, the Protocol Relating to the Madrid Agreement, was concluded in 1989 and aimed to simplify the application of registrations and costs and has 104 members after amendments.

Still, in the Iberian Peninsula, the Lisbon Agreement for the Protection of Appellations of Origin and their International Registration was signed in 1958. This agreement was the first specifically for Appellations of Origin, while the others had a broad spectrum of IP and sought to establish a record base. Due to low adherence, it was revised in Stockholm in 1967, amended in 1979, and extended to all GI types with the Geneva Act, 2015. The revisions and amendments broadened the spectrum of protection of origin-related products to different region relation and country adhesion degrees. This agreement amplified an understanding and set a standard for GI protection.

Finally, the Trade-Related Aspects of Intellectual Property Rights (TRIPS) Agreement, the broadest agreement ever made in terms of IP was negotiated at the end of the Uruguay Round between 1989 and 1990, with all 164 constituent parties of the WTO as participants. The agreement establishes the fundamental parameters and shared understanding of all specific types of IP, including GI.

All the agreements aimed to establish a common understanding of the standardization of rules to protect producers and consumers, mediated by the states as beacons of specific markets. Countries and economic blocs sought through this type of unifying document to improve and facilitate trade relations with each other in order to unify and standardize procedures and treatments. This standardization provided by the agreements and treaties guarantees the differentiation of certain goods through IP. By creating this differentiated treatment and following different rules for their production and commercialization, states establish a new market. Therefore, states seek the stabilization of markets through institutional conditions [16], which constitutes embeddedness. This embeddedness is central to the economic perception of the agri-food market beyond formal economic rules. This phenomenon occurs due to the state's interference in the rules in favor of interest groups, therefore determining the market's functioning. 


\subsection{Institutions of Economic Blocs}

The use of the term "institutions" for studying social phenomena starts with Durkheim and Weber and has gained new impetus with the New Economic Sociology (NES). The first study [17], when dealing with "exchange-related institutions," focuses on the production, exchange and distribution of wealth from the social division of labor [18-20]. From this derivation of "market," the author analyzes social relations of a constructive nature. The second study [21], when analyzing the construction of social activity in the exchange action, differs from the first in understanding the mercantile process as a composition between customs, legal conventions, and the State's role beyond the law [20]. In short, while for Durkheim institutions determine behavior, for Weber they guide behavior [20].

Several authors started to discuss its use in social actions years after the term became established in the most varied social sciences. Recently, several academics have felt the need for a definition. After all, what are institutions? Hodgson (2006) [22] (p. 2) defines that "Institutions are the kinds of structures that matter most in the social realm: they make up the stuff of social life." North (1991) [23] (p. 97) says that "Institutions are the humanly devised constraints that structure political, economic and social interaction. They consist of both informal constraints and formal rules". The latter is similar to the concept used by Acemoglu and Johnson (2005) [24], which still highlights the relevance of property rights institutions and contracting institutions, which are not usually mentioned in contemporary works. All of them converge in the broad sense that institutions consist of formal and informal social arrangements that influence collective social actions.

With this vital point resolved, the following subsection will clarify the specifics. Thus, it is necessary that, under these conditions, we analyze both the EU and Mercosur as institutions. Moreover, formal rules construct these entities and create so-called institutions. These rules are based on cooperative purposes between the countries that constitute them once they seek advantages by approximating each other. As previously mentioned, they are entities of different natures, but both with the purpose of, among other matters, promoting and facilitating trade between its members.

Mercosur came about with the Treaty of Asunción in 1991. Initially, it consisted of a free trade zone and became a customs union in 1995 between Brazil, Argentina, Paraguay and Uruguay. Subsequently, in 2012, Venezuela joined, and today are suspended. Additionally, Chile, Peru, Bolivia and Colombia, Ecuador, Guyana and Suriname became associated states. Despite its foundation's strictly commercial nature, the Ouro Preto Protocol of 1994 established a basic structure and advisory bodies for its operation. Today, it still has a commission of representatives and a secretariat among working subgroups and meetings. Mercosur grew and took, adopting integrative measures such as migration and regulatory issues shape in addition to commercial matters. However, due to the region's political instability, little progress has been made in recent years.

The EU, originating in the European Coal and Steel Community (ECSC) in 1952 and the European Economic Community (EEC) in 1957, took its first steps towards effective transnational regional integration. However, with some other agreements in the years that followed, it was only in 1992 that the entity was formalized as it stands with the Maastricht Treaty. Today, 27 countries constitute the EU, which functions as a political and economic union, which guarantees free transit of goods and people, with a single supra-state executive, legislative and judicial system and a joint regional and agricultural development policy, in addition to a single currency. With this apparatus, it constitutes the largest supra-national institution in the world.

In this way, both economic blocs constitute, to a greater or lesser degree, institutions capable of influencing the markets' direction in their respective regions and causing embeddedness through their regulations.

\subsection{Property Rights and the Influence of Institutions}

At the beginning of the 20th century, Weber had already addressed social action as an object of study. Moreover, it is also part of the market, ratified by Granovetter (1985) [12]. One 
must understand the market as social structures due to social constructions [25-29] resulting from how institutions participate in economic action. Thus, as defined by Abramovay (2004) [26] (pp. 35-36), markets are "recurrent and standardized forms of relationships between actors, maintained through sanctions." Thus, the Weberian perspective of the market formation allows us to analyze how the different actors, located in a given exchange arena, operate exchanges as institutions with the State as a mediator through the rules [20].

From the NES' re-foundation, through Granovetter's (1985) work, the understanding of economic phenomena, particularly the markets, takes on a meaning other than classical and neoclassical logic and rejects an optics explanatory monocausal derived from rationalism. The NES is based on groupings in favor of an adaptive struggle to maintain stability through cooperation by structures that constitute institutions, constituting embeddedness $[11,12,27,28]$. This approach to the markets opened a new field of thought, with proposals for approaches through the networks formed between the actors [30-32], through performance [33-35] and institutions [16,36-38]. In particular, the institutional approach seeks to answer questions related to markets' functioning through the configuration of social actions formed by the formal and informal rules of markets, power, and norms.

In the present context, the State plays a crucial role since, in every capitalist State, the economy's governance is a core activity in the process of state-building $[16,36,39]$. Due to such relevance of the state's participation over economic issues, property rights is characterized as a mechanism to structure the markets [40]. Through property rights, states assist, lead, or constrain economic organizations' forms and control the market's functioning [41]. These institutional acts are how state action constitutes a stable environment and conditions so that firms can organize, compete, cooperate, and transact so that neutrality becomes impossible [16]. Above all, works such as those by Allaire $(2010,2009)$ [13,42], Abramovay (2004) [26], and Barjolle et al. (2017) [43] highlight the relevance of the institutional approach to the GI market.

In this context, GI is an expression of the sociocultural embeddedness in the territory [44]. Such embeddedness is produced and sold to the consumers and involves a whole system of protection to guarantee legitimate goods and authentic properties that need a solid and trustable apparatus. To do that, each country or economic bloc developed its way to do it. However, as each system is different, the present work seeks to compare the differences between the two.

How does state action interfere in the agri-food products market with GI? One of the mechanisms used is how they conceive and create the environment so that actors can participate and transact, also creating the formal rules established by law and international agreements that deal with and regulate property rights. In practical terms, GIs as an intellectual property item have in these legal strata the manifestation of the state's will and the power to promote and control it. Therefore, it is in national laws, regional laws such as those of Mercosur and the EU and global agreements, such as Trade-Related Aspects of Intellectual Property Rights (TRIPS) and others that institutions realize their interests.

\subsection{GIs in Back Panels}

A third theoretical aspect is the need to highlight the situation of GIs between the EU and Mercosur. Despite the quantitative difference in GIs recorded in each block, all member countries of each bloc have operating systems capable of representing the best that each one offers. However, while the EU has operated a system informally for thousands of years and has a single regulation with reasonably well-defined rules, Mercosur still seems to be building a system that may one day be unified among all South American countries. Therefore, what is the current GI situation in these two blocs?

On the South American side, the two most notorious cases are Brazil and Argentina. For example, Argentina has 107 Argentine products registered with GIs, of which 99 are wines [45], and eight are from other agri-food products [46]. These numbers show a clear vocation and public attention to the development of the wine sector. Simultaneously, Brazil has 54 registrations of Brazilian products with GIs with diverse product types, including 
wines, cheeses, fruits and coffee [47]. These figures open up the reality of this market's maturation stage in Mercosur. The two largest record holders in the bloc combined do not even have 200 GIs, denoting a clear situational gap.

On the European side, the Mediterranean countries are the most quantitative highlights of registering products with GI. For example, as the pioneer in this market, Portugal has 191 registrations of national products with GIs; 40 are wines [9]. These numbers demonstrate a solid base of products with unique characteristics and ready for the market, considering the little more than 92 thousand square kilometers and its little more than ten million inhabitants. In the country with the most significant number in registrations, Italy, the figures give an even more robust picture of this market. With 861 records of GIs and 524 wines [9], the country shows full aptitude and an apparent strategic reference for the agri-food market.

The numbers of GI registrations are insufficient to exhaust the argumentative basis regarding this market model's performance, either as a commercial strategy, cultural recognition or a protection model. Therefore, it requires an in-depth analysis of the various aspects that permeate this market. Thus, the presented scenario only illustrates how certain countries and regions choose geographic indication as an appropriate route for their agrifood products. The comparative analysis of each one's legal bases provides the opportunity to show how one of the possible elements impacts this market's development and factors such as the bureaucratic structure aimed at the subject, targeted public policies or tariff policy.

\section{Methodology}

Mercosur's and the EU's choices allows a contrast between two continental economic blocs with distinct food and market cultures. Besides the different nature, cooperative institutions have, as a fundamental concept, joint action as a development strategy. However, to compare them, this work pays attention to internal laws and international agreements as instruments that allow market comprehension. Therefore, this work seeks to reach its objective by building an analysis framework capable of comparing both blocs. Thus, looking at agreements, legal instruments and examining the schemes will support this analysis, with agreements' adhesion and structure dedicated to this market. To build a functional analysis framework it was first necessary to survey each bloc's norm.

A framework capable of supporting the investigation of a specific market such as agricultural products has three vertices: the state, consumers and producers [7,15]. One of the state's instruments to act in an embedded way occurs by creating this market's rules, creating this intermediate field [16,37]. This way, it creates a niche that compares the economic blocs of Mercosur and the European Union. The hypothesis defended by this work is that the active involvement of supra-state entities, through their legal instruments, favors the development of the market by strengthening the institutions by creating instruments that protect and promote the market in question. Therefore, to compare the systems, this work examines crucial aspects of each bloc:

(1) Are all countries in the economic bloc signatory to the TRIPS Agreement? Negotiated at the end of the Uruguay Round, the agreement establishes minimum commercial regulation standards regarding intellectual property, which came into force on 1 January 1995. The agreement's signing means sharing the same legal and minimum protection root of commercial assets of issue in this work.

(2) Are all countries in the economic bloc signatory to the Lisbon Agreement for the Protection of Appellations of Origin and their International Registration? This agreement, signed on 31 October 1958, guarantees protection to all other members when something is registered in one of them. Additionally, revised in Stockholm in 1967 and amended by the Geneva Act in 2015, the agreement attests that the products registered with GI have characteristics attributed exclusively or essentially by factors intrinsic to the region, whether natural or human. 
(3) Does the economic bloc centralize or decentralize the norm? The question raised in this item is whether the bloc's legislation is uniform for members or whether each country has its own. The answer may indicate ease or difficulty of understanding the asset for its citizens and consequent commercialization.

(4) What are the objectives of the legal instrument? This question aims to identify whether the subject of GI to its participants treats consumers and producers as merely protective, if the meaning of the legislation promotes these markets, or if it is mixed.

(5) What is the role of the bloc in conducting the process? According to each bloc's legal text, it is possible to categorize the bloc's role and the respective interference and regulation of this market to categorize the bloc as interfering or neutral.

(6) Is there a graphical representation? Is there a unique graphic representation for the economic bloc products that can unify the consumer's understanding of GIs' meaning?

(7) Is there a different treatment for specific products? This question denotes the details of the legal instrument for products with GI.

(8) What type of intellectual property protection does the country use? There are three leading possible modalities: sui generis, collective or certification marks and methods focusing on business practices based on unfair competition. The modality chosen by the bloc may indicate the ease of uniformity which strengthens or weakens its institutional aspects.

(9) Is there a specific structure for the theme within the economic bloc? This question seeks to answer if there is a formal instance of discussion and deliberation regarding GIs over the economic bloc. The existence and function of such a space may indicate how both treat the matter.

Finally, facing all the answers obtained among the data referring to the absolute number of records per bloc, area, and population also contribute to this market's dimension. Then, a table shows where it is possible to see the differences in each case. This table synthesizes this research's results intuitively and elaborates on some partial conclusions about the agri-food products market's functioning with GIs. This theoretical framework sheds light on the relationship between the legal provisions and their influence over the market's institutions. The results can point to the importance of a well-developed GI system and allow inferences about models to be adopted.

Subsequently, we built a comparing table between economic blocs. Demographic data, such as area and population, among the number of GI records, state the present impacts of regulation effects. Thus, it will be possible to analyze the two blocs with a greater degree of accuracy and relevance to the sectors where formalized institutional structure has a greater weight. The parameters of area and population are more suitable for comparison than economic data due to the factors that imply characterizations of such products, natural or human, which characterize GI products.

The data referring to each economic bloc come from EU legislation and agreements signed by the Mercosur. Global spectrum agreements come from the WIPO and WTO documents. The GI records data are from the European Commission and the database of each country in Mercosur. As for demographic data, these follow according to the official availability of each bloc.

\section{Results}

As the investigation result, the answers to the previous section's questions were collected and adjusted according to an organized theoretical framework that allows better visualization of these exact results. Therefore, the results are more evident when pointing out the paths toward conclusions. Along with the answers that support the framework, the results also include economic data about the blocs so that the comparison can stand and sustain the analysis and the GI numbers, which is essential for a fair discussion of the differences of the blocs. 


\subsection{Mercosur}

The Southern Common Market (Mercosur) started on 26 March 1991, following the Treaty of Asunción in the same year founded by Argentina, Brazil, Paraguay and Uruguay. Subsequently, in 2012, Venezuela joined the bloc which still has Bolivia in accession, while seven states are associated: Bolivia, Chile, Colombia, Ecuador, Guyana, Peru and Suriname. There are also two other observers of the bloc: New Zealand and Mexico.

The bloc started as a free trade area and since 1995 it has become a customs union. Today, it has purposes beyond the promotion and commercial development of its members. It aims to promote cultural and educational integration and the circulation of goods and people between member countries. Despite constant political divergencies, the bloc is still active and has all of its foundations sustained through agreements and protocols. Next, we present the results. Thus, each question asked in the previous section has its numerical correspondent as follows below.

(1) Yes. All five Mercosur members have been signatories to the agreement and members of the WTO since 1 January 1995. Thus, all members are subject to the same fundamental legal basis, meaning that everyone has a convergence in understanding the theme.

(2) None of the Mercosur countries have signed neither the Lisbon Agreement nor the Stockholm Act nor the Geneva Act. Therefore, the conception of protection between the countries may differ, and its extension is not guaranteed between the other signatories.

(3) There are only two transnational pieces of legislation within the scope of Mercosur. The Protocol for Harmonization of Standards on Intellectual Property in Mercosur in Matters of Marks, Indications of Source and Designations of Origin and the Protocol for Harmonization of Standards in Industrial Design matters. In 1995, Paraguay, Uruguay and Venezuela ratified the first and the second, in 1998, was ratified only by Venezuela. Even though it was in force in all the bloc countries, the Harmonization Protocol of norms about IP leaves to each of its members' discretion the way to treat this issue domestically. The Mercosur agreement aims at "being able to grant broader protection" [48], establishing only the nomenclature of the characterizable labels, Designation of Origin and Indication of Source.

(4) Considering the Harmonization Protocol [48], all terms used in the agreement are in the sense of guaranteeing protection for producers and consumers. This document, concerning indications of origin and designations of origin, indicated as the "Obligation to Protect," according to the final intentions of the beginning of "promoting effective and adequate protection to intellectual property rights" [48].

(5) The Mercosur Harmonization Protocol does not establish any obligation to its members regarding this market besides guaranteeing protection and equal treatment between its partners' products. Therefore, there is no uniform regulatory interference, it is characterized as neutral.

(6) There is no single graphical representation for all members. It is up to each member to define whether there is at least one graphical representation for the whole country. In the South American case, each makes use of a different pattern. While each record has a graphical representation in Brazil, Uruguay has no clarity since it determines that GIs are the geographical names without restricting them. Although agri-food products may also have their representations in Argentina, national labels are expected to be used, which does not apply to wines. Finally, Paraguay foresees standardized national labels resembling the Argentinian case.

(7) In the Harmonization Protocol, there is no different treatment for any category of products, and therefore all should be treated equally.

(8) Meanwhile, Argentina and Uruguay use a genuine sui generis interpretation for their GI system. Brazil uses a predominant sui generis system but allows other interpretations due to specific cases such as cachaça. Paraguay, on the other hand, 
has legislation closer to collective or certification marks. Therefore, Mercosur has a heterogeneous manner of protection.

(9) Regarding Mercosur's organogram [49], working subgroup number eight regards agriculture. Additionally, there are specialized meetings dedicated to cooperative associations and to family farming. However, both specialized meetings are dedicated to related subjects, and there is no specific direction towards GI on the agenda. Therefore, despite instances of having discussion, Mercosur does not have a specific structure to address the matter.

\section{2. $E U$}

The EU is a bloc made up of 27 members from the European Economic Community formed in 1957. In 1993, by the Treaty of Maastricht, the European Union was established, and revised by the Lisbon Treaty in 2009. The EU functions as a supranational institution system through the European Council, European Commission, Council of the European Union, European Parliament, Court of Justice of the European Union, European Central Bank and the European Court of Auditors. In addition to a common market, this supranational system forms harmonizing monetary, migratory, agricultural and developmental policies, among others, so that there is a standard regulation capable of guiding each member country's policies and legislation. For this stage, this work focuses on the elementary regulations in force in the European Union. Next, we present the results. Thus, each question asked in the previous section has its numerical correspondent as follows below.

(1) Yes. All 27 members have been signatories to the agreement, members of the WTO and have signed the agreement on different dates. Thus, all members are subject to the same fundamental legal basis, meaning that everyone has a convergence in understanding the theme.

(2) At the Lisbon Agreement, all EU members did not initially sign it, nor did the EU formally exist. However, on 25 February 2020, the EU signed the Geneva Act, and it became a homogeneous system for all members. This way, the bloc guarantees protection for all countries' registrations, and there is a standardization of understanding of the protection.

(3) Among the primary legislation, there is a normative set for the entire economic bloc that still separates agri-food products [50], wines [51,52], aromatized wines [53] and spirits [54]. These documents create a set of general rules that member countries must follow. This allows members to adopt national rules, as provided for in Regulation 1151/2012, Article 28, stating that "Member States may maintain national rules on optional quality terms which are not covered by this Regulation, provided that such rules comply with Union law." However, this regulation does not restrict the GIs. Therefore, the EU set of rules centralizes the understanding of the GI approach in the European bloc.

(4) In Regulation (EU) 1151/2012, in Article one-General Provisions, where it constitutes the objectives of the legislation in question, it establishes four reasons for ensuring: (a) fair competition for farmers and producers of agricultural products and foodstuffs with value-adding characteristics and attributes; (b) the availability to consumers of reliable information about such products; (c) respect for intellectual property rights; and (d) the integrity of the internal market, like the specific objectives regarding GIs, contained in Article four of the same regulation. All items must attribute value to this market for promotion and the concrete protective connotation with European producers.

(5) It is clear from the regulations of Regulations (EU) 1151/2012, 1306/2013 and 1308/2013 that, in addition to the objectives already presented, these documents also relate to the Common Agricultural Policy (CAP), which deals with measures to encourage agricultural production across the bloc. Thus, they aim to protect their products and producers and establish minimum qualitative parameters to develop this market. Therefore, the role of the bloc is characterized as interventionist. 
(6) Yes. The Commission Delegated Regulation (EU) No 664/2014 [55] establishes the symbols to be used in all products with GI by the block members, such as Protected designation of origin (PDO), Protected geographical indication (PGI) being optional for wines in all cases and Traditional speciality guaranteed (TSG), mandatory for all products.

(7) Yes. There are different regulations between agri-food products, wines, spirits and aromatized wines [50-54].

(8) The EU utilizes a sui generis system. A special regime designed to protect the GIs of the bloc. The design used by the EU is well known and recognized as the first reference for the theme worldwide.

(9) There are two organizations in the EU's system that relate to GIs. First, the European Union Intellectual Property Office (EUIPO) and the Consumers, Health, Agriculture and Food Executive Agency (Chafea). EUIPO is related to legal issues, but Chafea has a specific sector dedicated to promoting agricultural products [56]. Therefore, the EU has a specific agency in charge of the subject.

\section{Discussion}

Once the collection of information from both blocs' legislation is complete, the respective results show a more in-depth analysis of the material is necessary. Table 1 shows the results that summarize the difference of regulation on both economic blocs. The table synthesizes that the EU, concerning Mercosur, has a unified regulation for all countries in the bloc, ensuring uniform market treatment; is not restricted only to the protection of products; has a more incisive character when interfering in regulation; it is also uniform in its interaction with the consumer; and differentiates the treatment of product categories.

Table 1. Comparison between the EU and Mercosur related to structure regulations.

\begin{tabular}{cccccccccc}
\hline Bloc/Item & $\mathbf{( 1 )}$ & $\mathbf{( 2 )}$ & $\mathbf{( 3 )}$ & $\mathbf{( 4 )}$ & $\mathbf{( 5 )}$ & $\mathbf{( 6 )}$ & $\mathbf{( 7 )}$ & $\mathbf{( 8 )}$ & $\mathbf{( 9 )}$ \\
\hline $\begin{array}{c}\text { Mercosur } \\
\text { EU }\end{array}$ & Yes & No & Decentralized & Protective & Neutral & No & No & Heterogeneous & No \\
& Yes & Yes & Centralized & Mixed & Interventionist & Yes & Yes & Homogeneous & Yes \\
\hline
\end{tabular}

Despite the TRIPS Agreement's signature by all members, Mercosur has also signed the treaty to standardize IPs as an instrument capable of sharing understanding, treatment and nomenclatures. Although, it has been shown as ineffective. Despite the signing of the treaty, its members with the largest economies, Brazil and Argentina, have not ratified it internally and therefore it has no validity. This fact harms the respective markets since there are no practical effects. It compromises the rule's protective nature since it does not apply in the countries with the largest economies in the bloc. However, all this considered, it maintains coherence when positioning regulatory interference as neutral.

Despite the differences as a type of bloc organization between the two, some instruments allow homogeneous treatment. However, the deployment option is different between cases. While Mercosur opted for a purely protective instrument, the EU adopts a protective system and promotes the market. Likewise regarding the regulations of both, while Mercosur aims to remain neutral in the market, the EU seeks the desired promoting effect through measures that interfere in order to ensure effectiveness. The nature of the constituted instances reinforces this conception within each organization.

Furthermore, while Mercosur has instances that only touch on the subject, the EU has an agency that addresses it incisively. The first one has open discussion spaces, which are essential, but they do not address the theme specifically. Nevertheless, that structure is coherent to a protective interpretation. Nonetheless, the EU's structure dedicates an agency towards promoting this market on an executive agency, which is also coherent to the bloc's perspective.

Another aspect that differentiates how each economic bloc treats its relationship to the market in question is using a distinctive sign for the entire block to facilitate the assimilation of consumers within that market. The EU also adopts differentiated regulatory treatment concerning wines and spirits whose impacts on the market need further study. 
This differentiation can bring essential elements to understand the market's functioning in countries with a relevant GI record portion, like Argentina and Uruguay.

Similarly, Table 2 presents the comparison between Mercosur and EU in socio-economic terms based on data from 2019. On the one hand, Mercosur has about $65 \%$ of the EU population. On the other hand, its area is close to three and a half times that of the EU, denoting a much greater population density in the European bloc. This difference allows analysis in two different but complementary forms. Additionally, there is more valuable information on economic matters. The first one is that the EU has almost four times Mercosur's Gross Domestic Product (GDP). It is a much greater market due to its economy; therefore, it is one of the main actors on the world stage. The second one is that the EU exports more than 12 times the value of Mercosur. This happens not only due to the number of countries or the bulkier economy but also partially due to the nature of the goods exported, which contain significant added value $[57,58]$.

Table 2. Comparison between the EU and Mercosur related to socio-economic numbers.

\begin{tabular}{|c|c|c|c|c|c|}
\hline Bloc/Item & $\begin{array}{l}\text { Population } \\
\text { (est.) }\end{array}$ & Area $\left(\mathrm{km}^{2}\right)$ & $\begin{array}{l}\text { GDP } \\
\text { (Trillions } \\
\text { USD) }\end{array}$ & $\begin{array}{l}\text { Exports } \\
\text { (Billions } \\
\text { USD) }\end{array}$ & $\begin{array}{l}\text { Main Agri-Food } \\
\text { Exported Products }\end{array}$ \\
\hline Mercosur & $\begin{array}{l}295,007,000 \\
{[59]}\end{array}$ & $\begin{array}{c}14,869,775 \\
{[59]}\end{array}$ & 4.169 [60] & 273 [57] & $\begin{array}{l}\text { Soybeans, corn, flour and } \\
\text { pellets (soybeans) and } \\
\text { frozen beef [ } 57]\end{array}$ \\
\hline EU & $\begin{array}{c}447,706,209 \\
{[61]}\end{array}$ & $\begin{array}{c}4,215,262 \\
{[62]}\end{array}$ & $15.621[60]$ & 3.357 [63] & $\begin{array}{l}\text { Wine (and related), } \\
\text { spirits and liqueurs, pork } \\
\text { meat and chocolate [64] }\end{array}$ \\
\hline
\end{tabular}

There is one other piece of information shown by Table 2, which is the main agri-food products that each bloc exports. While in Mercosur there is a concentration on commodities, the EU rather exports ones with some value added. This is a set of national economic strategies that this work does not intend to debate. However, the strategy adopted by the EU favors GI products, which label a value.

In a complementary way, the discrepancy in the number of records between the two blocs presented in Table 3 is striking. It may have historical origins and lacks an aligned commercial strategy capable of boosting this market's products. This factor is even more relevant in countries focused on the economy's primary sector, such as Brazil and Argentina.

Table 3. Comparison between the EU and Mercosur related to Geographical Indication (GI) numbers.

\begin{tabular}{ccccc}
\hline Bloc/Item & GIs Registered & Wines & $\begin{array}{c}\text { Spirits and } \\
\text { Aromatized } \\
\text { Wines }\end{array}$ & Others \\
\hline Mercosur & $210[45,65-68]$ & $140[45,65-68]$ & $3[45,65-68]$ & $67[45,65-68]$ \\
EU & $3336[9]$ & $1616[9]$ & $247[9]$ & $1473[9]$ \\
\hline
\end{tabular}

Mercosur adopts independent and neutral-protective measures which are a counterpoint to the EU's situation. The European economic bloc has more active instruments regarding the GI products approach. The work presents evidence of different treatments on legal aspects. Systems such as the South American system work on low capacity tools for market development. On the other hand, the European system embedded a more proactive institution resulting in a more dynamic market. The result of this comparison reflects on the number of registrations in each of the markets. Both tables' allows us to infer that more active, integrated and robust normative systems provide institutions (in this case, the market) with more efficiency. The demographic data contribute to understanding of the magnitude of the difference in effects resulting from the approaches. Moreover, the mere adoption of the general guiding parameter for GIs' basic understanding does not mean that this IP modality's assimilation will be homogeneous among the adhering entities. 
Still, in comparison to Mercosur, the EU presents a more significant number of registrations. This number becomes even outstanding in relative terms since its area is smaller than that of the South American bloc. Additionally, despite reports of origin-related products being much older than in the Americas, the oldest records in the current mold date from 1973 in France [9]. Therefore, the high registration numbers are a credit to the European group of countries' organizations. The standardization of norms and an interventionist posture of the institutions allows market promotion and collective strategies, such as using a single label.

The demographics illustrate the significant difference. Data such as area and population are more relevant to the present analysis due to the factors that embed the GI products and, furthermore, the market. Since GI products are social constructions based on natural, human and historical factors [69], population and area are adequate measures to influence the market. People play a role in human factors, and area allows different natural effects over agricultural products. However, historical effects could be crucial to this market and need further studies in both regions.

The hypothesis defended by this work is therefore sustained. The presented evidence supports that supra-state entities' active involvement, through their legal instruments, favors the market's development by strengthening the institutions and promoting the market in question. On the other hand, legal instruments' mere existence or adoption of a broad spectrum of rules does not necessarily impact positively. Furthermore, the broader the measures, the weaker the ties that bind and embedded the institutions are.

The results of this investigation suggest that the arguments of Stone Sweet et al. (2001) [70] and Fligstein $(1996,2008)[16,71]$ also provide support in the niches of agricultural markets, especially in GI. The factors that create effective institutions through cooperative means can boost political and cultural aspects, triggering development such as of the GI market. In this way, the EU model can be used as a reference and indicate a possible path for the market in question, depending on each region's reality. However, the reasons why some countries develop differently from others within the economic bloc require further attention.

Beyond Fligsteins's approach, there is evidence that broader spectrum agreements have little influence on the institutions and, therefore, on the markets. On the other hand, narrower agreements such as the Lisbon Agreement for the Protection of Appellations of Origin and their International Registration and its amendments bind the participants to instruments, promoting homogeneity and strengthening the institutions which promote the market. The proposition to build a unique understanding by the EU results other blocs and countries to format a system to protect such culturally related goods and create the notion of control.

Markets are based on a relationship of trust between buyers and sellers, on a willingness to cooperate $[72,73]$. Due to this, trust becomes a central aspect of this market's success or failure. The adhesion of producers and their formal groups to official GI schemes and consumers that recognize GI labels as trustable makes national and supranational institutions the vehicle that gives trustworthiness to both sides. These institutions are the glue of trust in the GI system designed to protect and promote this specific market. Therefore, by strengthening the institutional parameters, there is a heightening in the trustworthiness of the scheme. This trust results in greater participation by producers and consumers of such goods. The trust results in a more reliable, standard and established system reflected by the large number of GI registrations in the EU.

The results indicate that standard legal structures among promotive measures and intentions fortify the institutions and facilitate commerce, developing these products' market. Additionally, the area and population have little influence over product registrations, even though they are the characterizing factors for such goods, if not followed by proper institutional tools. The evidence suggests that the strengthening of institutions designed through cooperation and harmonization towards the theme promotes trustable GI schemes allowing market development. In both cases, binding agreements and narrower under- 
standing and devoted institutional structures and standardization reinforce the instruments that strengthen the system. The most efficient system responds to well-defined structures designed to promote the market and tied to elements capable of promoting and protecting it. Such efficiency overcomes the compared lack of natural factors that could influence the number of GI products.

\section{Conclusions}

In summary, the present work demonstrates the parallel situation between two economic blocs, Mercosur and the EU, through a qualitative analytical matrix explicitly built to understand the legal framework that influences the institutions involved. Additionally, it investigates the possible causes arising from the State or its organizations expressed in the normative-legal framework to regulate, protect and promote the market for GI agri-food products.

The results show that the European bloc numbers are significantly higher than those of the South American bloc, a relationship that also expresses the countries selected in absolute terms. The proportionate results are even more expressive considering the area of both and attenuated in populational terms. These conclusions reinforce Fligstein's (2008) [71] argument that the EU is a social organization model that favors the bloc's political, cultural and commercial dynamics. Additionally, this investigation's results must be overlooked through the lens of the bloc's economic strategy. The numbers presented in Table 2 show that value addition to agri-food products could proportionate dividends and development to the countries.

The standardization of norms and uniformity of understanding for developing a common and shared strategy among commercial partners is crucial for GI products' commercial performance. However, the narrowness or wideness of the norms tends to influence the standardization effectiveness severely. The existing correlation between uniformity and standardization of norms, combined with state interventions geared towards their promotion, demonstrates the relevance of this market's success. This argument is reinforced by the formal structures within the bloc designed to address the issue. However, it cannot establish sufficient cause for it and the differentiation of standards for specific products. Further research over products such as wine might show more evidence of the relevance of bureaucracy-related structures. Likewise, the results show that adherence to broadspectrum agreements is positive since it is a step towards standardization on the topic. However, they are not enough to develop the market. Narrower agreements and specific offices with institutional intentions have been shown to be more effective, and innovative structured measures can build a perception of control for the institutions.

The first conclusion is that the signing of broad-spectrum protection agreements, by itself, does not guarantee the full development of the covered market. Although it is positive, the narrower the agreements, the stronger the bind to standardization and strengthening of the institutions. The second conclusion is that the more legal instruments that are politically active, the more significant the GI records' quantitative impact. The third is that instruments aimed at promoting the market beyond the protection of producers and consumers and centralizing understanding and labeling favor the institutional tools to used develop this market. The fourth is that the initiative to build measures towards a universal understanding and pioneer instruments to strengthen the institutions creates a conception of control that tends to be followed. The fifth is that institutional structures designed to promote the GI scheme can strengthen the market. After all, the EU has developed a more robust, promotive and uniform system through its legal basis than Mercosur and, therefore, is more capable of protecting and promoting its GI products. The sixth and last conclusion is that a more reliable, standard and established system reflects on the system's trustworthiness and implies more participation from both consumers and producers. This includes a higher number of registrations and protections granted. This work's findings complement other works on the role of institutions' relevance to governance $[15,74]$. 
Finally, the number of registrations expresses the significance as far as the instruments are present in the market. There is a tendency to facilitate trade between the states involved when institutions operate cooperatively and are dedicated to a defined purpose. The potential differences that act over GI products' characterization, such as human and natural elements, have little effect on the number of registrations if not followed by organized supranational standard institutional elements. However, both this last aspect and the differentiation of labeled products still need further study.

Other elements, such as producers and consumers, may also be decisive in this market and need further study, including in specific and distinct categories of products, GI typology and the economic impact of using a single label. More in-depth country and theoretical investigations, especially in the EU, are necessary. Despite having the same basic rules, countries seem to perform differently as Mediterranean ones. Therefore, more work is necessary and can bring findings on the roots of productive vocations and social relations developed from culturally related agri-food products. Likewise, investigations related to products strongly related to countries and their market development can bring valuable information to academics, practitioners and authorities.

Funding: This research received no external funding.

Institutional Review Board Statement: Not applicable.

Informed Consent Statement: Not applicable.

Data Availability Statement: Data sharing not applicable.

Acknowledgments: The author wishes to thank Manuel Pacheco Coelho and Daniel S. Lopes from the Lisbon School of Economics and Management for the research support and assistance over the research and SOCIUS colleagues. Additionally, the author would like to thank the reviewers for their precious advice.

Conflicts of Interest: The views and opinions expressed in this article are those of the author and do not necessarily reflect the official position of the Brazilian Ministry of Agriculture, Livestock and Food Supply.

\section{References}

1. Allaire, G.; Sylvander, B. Qualité Spécifique et Systèmes d'innovation Territoriale. Cah. Econ. Sociol. Rural. CESR 1997, 44, 29-59.

2. Bonanno, A. Geographical indication in agri-food and its role in the global neoliberal era: A theoretical analysis. In Geographical Indication and Global Agri-Food: Development and Democratization; Earthscan Food and Agriculture; Routledge: New York, NY, USA, 2020; p. 240. ISBN 978-0-429-47090-5.

3. Akerlof, G.A. The Market for "Lemons": Quality Uncertainty and the Market Mechanism. Q. J. Econ. 1970, 84, 488. [CrossRef]

4. Tonietto, J. O Conceito de Denominação de Origem: Uma Opção Para o Desenvolvimento do setor Vitivinícola Brasileiro; Embrapa Uva e Vinho: Bento Gonçalves, Brazil, 1993.

5. WTO. Agreement on Trade-Related Aspects of Intellectual Property Rights (TRIPS); WTO: Geneva, Switzerland, 1994.

6. Parrott, N.; Wilson, N.; Murdoch, J. Spatializing Quality: Regional Protection and the Alternative Geography of Food. Eur. Urban Reg. Stud. 2002, 9, 241-261. [CrossRef]

7. Ilbery, B.; Kneafsey, M. Niche Markets and Regional Speciality Food Products in Europe: Towards a Research Agenda. Environ. Plan. Econ. Space 1999, 31, 2207-2222. [CrossRef]

8. Curro, R.J.d.P. Mercosul: A Moeda Única e Suas Conseqüências No Comércio Internacional; Universidade de São Paulo: São Paulo, Brazil, 2009.

9. European Comission EAmbrosia-The EU Geographical Indications Register. Available online: https: / /ec.europa.eu/info/foodfarming-fisheries / food-safety-and-quality / certification/quality-labels/geographical-indications-register/\# (accessed on 26 March 2020).

10. Campos, A.T. A Proteção das Indicações Geográficas nos Países do Mercosul. Dissertação (Mestrado Profissional em Propriedade Intelectual e Inovação), Academia de Propriedade Intelectual, Inovação e Desenvolvimento, Coordenação de Programas de Pós-Graduação e Pesquisa; Instituto Nacional da Propriedade Industrial-INPI: Rio de Janeiro, Brazil, 2018.

11. Fligstein, N.; Dauter, L. The Sociology of Markets; Social Science Research Network: Rochester, NY, USA, 2007.

12. Granovetter, M. Economic Action and Social Structure: The Problem of Embeddedness. Am. J. Sociol. 1985, 91, 481-510. [CrossRef]

13. Allaire, G. Applying Economic Sociology to Understand the Meaning of "Quality" in Food Markets: Applying Economic Sociology to Understand the Meaning of "Quality" in Food Markets. Agric. Econ. 2010, 41, 167-180. [CrossRef] 
14. Schneider, S. Mercados e Agricultura Familiar. In Construção de Mercados e Agricultura Familiar: Desafios para o Desenvolvimento Rural; Marques, F.C., Conterato, M.A., Schneider, S., Eds.; Capítulo 4; Editora da UFRGS: Porto Alegre, Brazil, 2016 ; pp. 93-142. ISBN 978.85.386.0297.2.

15. Belletti, G.; Marescotti, A.; Touzard, J.-M. Geographical Indications, Public Goods, and Sustainable Development: The Roles of Actors' Strategies and Public Policies. World Dev. 2017, 98, 45-57. [CrossRef]

16. Fligstein, N. Markets as Politics: A Political-Cultural Approach to Market Institutions. Am. Sociol. Rev. 1996, 61, 656. [CrossRef]

17. Durkheim, E. De La Division Du Travail Social (The Division of Labour in Society); Alcan: Paris, France, 1893; Available online: http:/ / archive.org/details / deladivisiondutr00durkuoft (accessed on 1 March 2021).

18. Aron, R. As Etapas Do Pensamento Sociológico; Leya: Lisbon, Portugal, 2016; ISBN 972-20-5680-8.

19. Nau, H.H.; Steiner, P. Schmoller, Durkheim, and Old European Institutionalist Economics. J. Econ. Issues 2002, 36, 1005-1024. [CrossRef]

20. Raud-Mattedi, C. A construção social do mercado em Durkheim e Weber: Análise do papel das instituições na sociologia econômica clássica. Rev. Bras. Ciênc. Sociais 2005, 20. [CrossRef]

21. Weber, M. Economy and Society: A New Translation; Harvard University Press: Cambridge, MA, USA, 2019; ISBN 0-674-24083-9.

22. Hodgson, G.M. What Are Institutions? J. Econ. Issues. 2006, 40, 1-25. [CrossRef]

23. North, D.C. Institutions. J. Econ. Perspect. 1991, 5, 97-112. [CrossRef]

24. Acemoglu, D.; Johnson, S. Unbundling Institutions. J. Polit. Econ. 2005, 113, 949-995. [CrossRef]

25. Abramovay, R. A rede, os nós, as teias: Tecnologias alternativas na agricultura. Rev. Adm. Pública 2000, 34, $159-177$.

26. Abramovay, R. Entre Deus e o diabo: Mercados e interação humana nas ciências sociais. Tempo Soc. 2004, 16, 35-64. [CrossRef]

27. Fligstein, N. Social Skill and the Theory of Fields. Sociol. Theory 2001, 19, 105-125. [CrossRef]

28. Smelser, N.J.; Swedberg, R. (Eds.) The Handbook of Economic Sociology, 2nd ed.; Princeton University Press; Russell Sage Foundation: Princeton, NJ, USA, 2005; ISBN 978-0-691-12125-3.

29. Steiner, P. A Plea for a Weberian Economic Sociology-Mark Granovetter, Society and Economy. Framework and Principles (The Belknap Press of Harvard University Press, 2017). Eur. J. Sociol. Arch. Eur. Sociol. 2017, 58, 545-547. [CrossRef]

30. Burt, R.S. Structural Holes: The Social Structure of Competition; Social Science Research Network: Rochester, NY, USA, 1992.

31. White, H.C. Where Do Markets Come From? Am. J. Sociol. 1981, 87, 517-547. [CrossRef]

32. White, H.C. Markets from Networks: Socioeconomic Models of Production; Princeton University Press: Princeton, NJ, USA, 2002; ISBN 978-0-691-12038-6.

33. Callon, M.; Méadel, C.; Rabeharisoa, V. The Economy of Qualities. Econ. Soc. 2002, 31, 194-217. [CrossRef]

34. Callon, M.; Muniesa, F. Economic Markets as Calculative Collective Devices. Organ. Stud. Organ. 2005, 26, 1229-1250. [CrossRef]

35. Mackenzie, D. An Engine, Not a Camera: How Financial Models Shape Markets; MIT Press: Cambridge, MA, USA, 2008; ISBN 978-0-262-25004-7.

36. Dobbin, F. Forging Industrial Policy: The United States, Britain, and France in the Railway Age; Cambridge University Press: Cambridge, UK, 1994; ISBN 978-0-521-62990-4.

37. Fligstein, N. The Architecture of Markets: An Economic Sociology of Twenty-First-Century Capitalist Societies; Princeton University Press: Princeton, NJ, USA, 2002; ISBN 978-0-691-10254-2.

38. Powell, W.W.; DiMaggio, P.J. The New Institutionalism in Organizational Analysis; University of Chicago Press: Chicago, IL, USA, 2012; ISBN 978-0-226-18594-1.

39. Fligstein, N. The Transformation of Corporate Control; Harvard University Press: Cambridge, MA, USA, 1990; ISBN 978-0-674-903593.

40. Walder, A.G.; Luo, T.; Wang, D. Social Stratification in Transitional Economies: Property Rights and the Structure of Markets. Theory Soc. 2013, 42, 561-588. [CrossRef]

41. Campbell, J.L.; Lindberg, L.N. Property Rights and the Organization of Economic Activity by the State. Am. Sociol. Rev. 1990, 55, 634-647. [CrossRef]

42. Allaire, G. Economics of Conventions and the New Economic Sociology and Our Understanding of Food Quality and New Food Markets and Trade Institutions What Are Markets That Pure Economics Does Not Know? In Proceedings of the Plenary Session 5 "The new landscape and the need for an extension to the agricultural economics toolkit"; 27th International Conference of Agricultural Economist, Beijing, China, 16-22 August 2009; p. 34. Available online: https://ageconsearch.umn.edu/record/53203 (accessed on 1 February 2021).

43. Barjolle, D.; Quiñones-Ruiz, X.F.; Bagal, M.; Comoé, H. The Role of the State for Geographical Indications of Coffee: Case Studies from Colombia and Kenya. World Dev. 2017, 98, 105-119. [CrossRef]

44. Cerdan, C. Indicações Geográficas e estratégias de desenvolvimento territorial. In Indicações Geográficas: Qualidade e Origem nos Mercados Alimentares; UFRGS: Porto Alegre, Brasil, 2013; pp. 125-150.

45. Instituto Nacional de Vitivinicultura Indicaciones Geográficas y Denominaciones de Origen Reconocidas y Protegidas de la República Argentina. Document, 2020. Available online: https://www.argentina.gob.ar/inv/proteccion-del-origen (accessed on 1 February 2021).

46. Argentina Indicación Geográfica y Denominación de Origen. Available online: http://www.alimentosargentinos.gob.ar/ HomeAlimentos/IGeo/productos_reconocidos.php (accessed on 15 June 2020). 
47. Brasil Lista de IGs Registradas. Available online: https://www.gov.br/agricultura/pt-br/assuntos/sustentabilidade/indicacaogeografica/lista-de-igs-registradas (accessed on 15 June 2020).

48. Mercosul Protocolo de Harmonização de Normas Sobre Propriedade Intelectual No Mercosul em Matéria de Marcas, Indicações de Procedência e Denominações de Origem. Asunción, Paraguay, 5 May 1995. Available online: https://www.mre.gov.py/ tratados/public_web/DetallesTratado.aspx?id=2ooBwPZqYBYDyHTjMx+HmQ\%3d\%3d (accessed on 1 February 2021).

49. Mercosur Organigrama. Available online: http://www.mercosur.coop/Organigrama (accessed on 8 March 2021).

50. European Union. Regulation (EU) No. 1151/2012; European Union: Brussels, Belgium, 2012.

51. European Union. Regulation (EU) No. 1306/2013; European Union: Brussels, Belgium, 2013.

52. European Union European Council. Regulation (EU) No. 1308/2013; European Union: Brussels, Belgium, 2013.

53. European Union. Regulation (EU) No. 251/2014; European Union: Brussels, Belgium, 2014.

54. European Union. Regulation (EU) 787/2019; European Union: Brussels, Belgium, 2019.

55. European Commission. Commission Delegated Regulation (EU) No 664/2014; European Union: Brussels, Belgium, 2013.

56. Chafea. Available online: https:/ / ec.europa.eu/chafea/agri/en (accessed on 8 March 2021).

57. COMITÉ TÉCNICO N 6 “Estadísticas del Comercio Exterior del MERCOSUR"; UTECEM/Secretaría del MERCOSUR Informe Técnico de Comercio Exterior. Available online: https:/ / estadisticas.mercosur.int (accessed on 11 March 2021).

58. Eurostat Main Goods in Extra-EU Exports—Statistics Explained. Available online: https://ec.europa.eu/eurostat/statisticsexplained/index.php/Main_goods_in_extra-EU_exports (accessed on 11 March 2021).

59. Mercosur Sitio Oficial del MERCOSUR. Available online: https:/ / www.mercosur.int/ (accessed on 25 November 2020).

60. International Monetary Fund Report for Selected Countries and Subjects. Available online: https://www.imf.org/en/ Publications/WEO/weo-database/2020/October/weo-report (accessed on 11 March 2021).

61. European Union Statistics I Eurostat. Available online: https://ec.europa.eu/eurostat/databrowser/view/tps00001/default/ table?lang=en (accessed on 25 November 2020).

62. European Union Eurostat-Data Explorer. Available online: http://appsso.eurostat.ec.europa.eu/nui/submitViewTableAction. do (accessed on 25 November 2020).

63. European Commission Access2Markets Statistics Page. Available online: https://trade.ec.europa.eu/access-to-markets/en/ statistics (accessed on 11 March 2021).

64. European Commission. Monitoring EU Agri-Food Trade: Developments in 2019; European Union: Brussels, Belgium, 2019.

65. Impulso de Denominaciones de Origen Fortalecen Producción Nacional I SAPI. Available online: http://sapi.gob.ve/impulso-dedenominaciones-de-origen-fortalecen-produccion-nacional/ (accessed on 26 November 2020).

66. INPI Pedidos de Indicação Geográfica no Brasil. Available online: https://www.gov.br/inpi/pt-br/servicos/indicacoesgeograficas / pedidos-de-indicacao-geografica-no-brasil (accessed on 26 November 2020).

67. Ministerio de Agricultura, Ganadería y Pesca Dirección Nacional de Alimentos y Bebidas-Indicación geográfica y Denominación de Origen. Available online: http://Www.alimentosargentinos.gob.ar/HomeAlimentos/IGeo/productos_reconocidos.php (accessed on 9 September 2020).

68. Prosur Proyecta Secreto Industrial. Available online: https://www.prosurproyecta.org/uruguay/categoria-explorador/secretoindustrial/ (accessed on 26 November 2020).

69. Barham, E. Translating Terroir: The Global Challenge of French AOC Labeling. J. Rural Stud. 2003, 19, 127-138. [CrossRef]

70. Stone Sweet, A.; Sandholtz, W.; Fligstein, N. The Institutionalization of Europe; Oxford University Press: Oxford, UK, 2001; ISBN 0-19-924796-X.

71. Fligstein, N. Euroclash: The EU, European Identity, and the Future of Europe; Oxford University Press: Oxford, UK; New York, NY, USA, 2008; ISBN 978-0-19-954256-7.

72. Granovetter, M. Society and Economy; Harvard University Press: Cambridge, MA, USA, 2017; ISBN 0-674-97521-9.

73. Beckert, J. Trust and the Performative Construction of Markets. Available SSRN 2465811. 2005. Available online: https://papers. ssrn.com/sol3/papers.cfm?abstract_id=2465811 (accessed on 1 February 2021).

74. Mancini, M.C. Geographical Indications in Latin America Value Chains: A "Branding from below" Strategy or a Mechanism Excluding the Poorest? J. Rural Stud. 2013, 32, 295-306. [CrossRef] 